\title{
Social Stress and CRF-Dopamine Interactions in the VTA: Role in Long-Term Escalation of Cocaine Self-Administration
}

\author{
Christopher 0. Boyson, ${ }^{1}$ Elizabeth N. Holly, ${ }^{1}$ Akiko Shimamoto,${ }^{1}$ Lucas Albrechet-Souza, ${ }^{1}$ Lindsay A. Weiner, ${ }^{1}$ \\ Joseph F. DeBold, ${ }^{1}$ and Klaus A. Miczek ${ }^{1,2}$ \\ ${ }^{1}$ Department of Psychology, Tufts University, Medford, Massachusetts 02155, and 2Departments of Psychiatry, Pharmacology, and Neuroscience, Tufts \\ University School of Medicine, Boston, Massachusetts 02110
}

The nature of neuroadaptations in the genesis of escalated cocaine taking remains a topic of considerable interest. Intermittent social defeat stress induces both locomotor and dopaminergic cross-sensitization to cocaine, as well as escalated cocaine self-administration. The current study examines the role of corticotropin releasing factor receptor subtypes 1 and $2\left(\mathrm{CRFR}_{1}, \mathrm{CRFR}_{2}\right)$ within the ventral tegmental area (VTA) during social defeat stress. This study investigated whether injecting either a $\mathrm{CRFR}_{1}$ or $\mathrm{CRFR}_{2}$ antagonist directly into the VTA before each social defeat would prevent the development of later (1) locomotor sensitization, (2) dopaminergic sensitization, and (3) escalated cocaine self-administration in rats. CRFR $_{1}$ antagonist CP376395 (50 or 500 ng/side), CRFR 2 antagonist Astressin $_{2}-\mathrm{B}$ (100 or $1000 \mathrm{ng} /$ side), or vehicle (aCSF) was microinjected into the VTA 20 min before social defeat stress (or handling) on days $1,4,7$, and 10 . Ten days later, rats were injected with cocaine (10 mg/kg, i.p.) and assessed for either locomotor sensitization, measured by walking activity, or dopaminergic sensitization, measured by extracellular dopamine (DA) in the nucleus accumbens shell (NAcSh) through in vivo microdialysis. Locomotor sensitization testing was followed by intravenous cocaine self-administration. IntraVTA antagonism of $\mathrm{CRFR}_{1}$, but not $\mathrm{CRFR}_{2}$, inhibited the induction of locomotor cross-sensitization to cocaine, whereas both prevented dopaminergic cross-sensitization and escalated cocaine self-administration during a $24 \mathrm{~h}$ "binge." This may suggest dissociation between locomotor sensitization and cocaine taking. These data also suggest that interactions between CRF and VTA DA neurons projecting to the NAcSh are essential for the development of dopaminergic cross-sensitization to cocaine.

\section{Introduction}

Stressful situations often precede intense drug taking behaviors (Goeders, 2002; Brady and Sinha, 2005; Miczek et al., 2008). Both clinical and preclinical studies have demonstrated that certain types of stress can play a major role in the initiation and escalation of, as well as relapse to, drug abuse (Shaham et al., 2000; Sinha, 2009). In rodents, intermittent social defeat stress engenders long-lasting neuroadaptations, resulting in locomotor and dopaminergic cross-sensitization as well as escalated cocaine self-administration during a $24 \mathrm{~h}$ "binge" (Nikulina et al., 2004; Miczek et al., 2011). Understanding the neurobiological mechanisms by which stress can increase the vulnerability to drug addiction is critical for the development of therapeutic interventions.

Stress may increase cocaine taking and seeking through action of the neuropeptide corticotropin releasing factor (CRF) via CRF

\footnotetext{
Received Sept. 13, 2013; revised March 14, 2014; accepted April 7, 2014

Author contributions: C.O.B., E.N.H., J.F.D., and K.A.M. designed research; C.O.B., E.N.H., A.S., L.A.-S., and L.A.W. performed research; C.O.B., E.N.H., A.S., J.F.D., and K.A.M. analyzed data; C.O.B. and E.N.H. wrote the paper.

This work was supported by National Institute on Drug Abuse Grant DA-031734. L.A.-S. was supported by CNPq-Brazil postdoctoral fellowship 202392/2012-0. We thank Tom Sopko for excellent technical skills in preparing the manuscript.

The authors declare no competing financial interests.

Correspondence should be addressed to Dr. Klaus A. Miczek, Bacon Hall, 530 Boston Avenue, Medford, MA 02155. E-mail: klaus.miczek@tufts.edu.

DOI:10.1523/JNEUROSCI.3942-13.2014

Copyright $\odot 2014$ the authors $\quad 0270-6474 / 14 / 346659-09 \$ 15.00 / 0$
}

receptor subtypes 1 and $2\left(\mathrm{CRFR}_{1}\right.$ and $\left.\mathrm{CRFR}_{2}\right)$ (Vale et al., 1981). CRF mediates many behavioral and physiological responses to stress and drugs of abuse (Koob, 1999; Weiss et al., 2001; Koob and Zorrilla, 2010). The primary role of CRF is to activate the hypothalamic-pituitary-adrenal axis by increasing the release of glucocorticoids in response to stress (Bale and Vale, 2004). In addition to the hypothalamic-pituitary-adrenal axis, CRF axons project to extrahypothalamic areas, including the amygdala, bed nucleus of stria terminalis (BNST), and ventral tegmental area (VTA) (Swanson et al., 1983; Sawchenko et al., 1993).

The VTA is a critical component of the mesocorticolimbic circuit associated with many functions of the dopamine (DA) system. Therefore, CRF release in the VTA may play a significant role in stress-induced escalation of cocaine self-administration. CRF release in the VTA can cause synaptic neuroadaptations of DA neurons within the mesolimbic pathway (Saal et al., 2003; Ungless et al., 2003; Borgland et al., 2004). CRF also increases the action potential firing rate of VTA DA neurons through $\mathrm{CRFR}_{1}$ (Wanat et al., 2008). CRFR 2 activation, on the other hand, along with CRF binding protein can produce a transient, slow-developing potentiation of $N$-methyl-D-aspartate receptor (NMDA) and metabotropic glutamate receptor transmission in a subset of dopaminergic VTA neurons (Fiorillo and Williams, 1998; Ungless et al., 2003).

In addition to different cellular effects, recent studies show $\mathrm{CRFR}_{1}$ and $\mathrm{CRFR}_{2}$ activation within the VTA may play varying roles in escalated cocaine self-administration and stress-induced 
reinstatement (Wang et al., 2005; Blacktop et al., 2011; Boyson et al., 2011). $\mathrm{CRFR}_{1}$ antagonism $20 \mathrm{~min}$ before social defeat stress can prevent the development of locomotor sensitization and escalated cocaine self-administration during a $24 \mathrm{~h}$ "binge" (Boyson et al., 2011). However, whether there is a dissociation in the role of these two receptor subtypes during social stress, and how they may differ with regard to dopaminergic function within the VTA, remains unclear.

The current study investigates whether microinjecting $\mathrm{CRFR}_{1}$ or $\mathrm{CRFR}_{2}$ antagonists into the VTA before social defeat stress can prevent long-lasting effects of (1) locomotor sensitization, (2) dopaminergic sensitization, and (3) escalated cocaine self-administration during a $24 \mathrm{~h}$ "binge."

\section{Materials and Methods}

Subjects

Experimental animals. Male Long-Evans rats (Charles River Laboratories) weighing 225-250 g upon arrival were individually housed in custom-built clear acrylic chambers $(30 \times 30.5 \times 24.5 \mathrm{~cm})$ with cellulose pellet bedding (Cellu-Dri, Shepherd Specialty Papers) in a separate vivarium from aggressive resident rats for at least 1 week before experimental manipulation. All rats were given ad libitum access to food and water and kept on an inverted $12 \mathrm{~h}$ light/dark cycle (lights off at $0800 \mathrm{~h}$ ) under controlled temperature $\left(21 \pm 1^{\circ} \mathrm{C}\right)$ and humidity $(35 \%-40 \%)$ throughout all phases of the experiments. All experimental procedures were approved by the Tufts Institutional Animal Care and Use Committee following the principles of the Guide for the care and use of laboratory animals).

Residents. Twenty additional male Long-Evans rats were pair housed with females in large stainless steel cages $(45.7 \times 71.1 \times 45.7 \mathrm{~cm})$ under the same housing conditions as the experimental animals to serve as aggressive stimulus residents. Before being used in these experiments, each resident had multiple encounters with naive intruders to ensure reliable aggressive behavior (Miczek et al., 1979).

\section{Experimental design}

The experimental design is depicted in Figure 1. Rats were randomly assigned to receive bilateral intra-VTA microinjections of CRFR $\mathrm{C}_{1}$ antagonist (CP376395 [CP], $50 \mathrm{ng} / 0.25 \mu \mathrm{l} /$ side or $500 \mathrm{ng} / 0.25 \mu \mathrm{l} / \mathrm{side}$ ), $\mathrm{CRFR}_{2}$ antagonist (Astressin $2-\mathrm{B},[\mathrm{A} 2 \mathrm{~B}], 100 \mathrm{ng} / 0.25 \mu \mathrm{l} /$ side or $1000 \mathrm{ng} / 0.25$ $\mu \mathrm{l} /$ side), or vehicle (aCSF) 20 min before either intermittent social defeat stress or handling on experimental days 1, 4, 7, and 10. Ten days later, on day 20, rats were tested for locomotor cross-sensitization, as described below, and were subsequently catheterized for intravenous cocaine selfadministration, which ended in a $24 \mathrm{~h}$ "binge." A separate cohort of rats was assessed for dopaminergic sensitization on day 20 by in vivo microdialysis of DA in the nucleus accumbens shell (NAcSh) (Fig. 1). The treatment groups and number of rats per group are specified in Table 1.

\section{Intracranial surgery}

After 1 week of habituation to the vivarium, rats were anesthetized with ketamine $(100 \mathrm{mg} / \mathrm{kg})$ and xylazine $(6 \mathrm{mg} / \mathrm{kg})$ and surgically implanted with bilateral stainless steel cannula (23 ga, $11 \mathrm{~mm}$ length, Plastics One) aimed $1 \mathrm{~mm}$ above the VTA using coordinates from a stereotaxic atlas (Paxinos and Watson, 1997) (anteroposterior: $-5.2 \mathrm{~mm}$ from bregma; mediolateral: $\pm 1.8 \mathrm{~mm}$ from midline; dorsoventral: $-7.5 \mathrm{~mm}$ from skull) at a $10^{\circ}$ angle (Boyson et al., 2011). Cannula patency was maintained by inserting obdurators between microinjections. Rats in the microdialysis experiment were also implanted with an additional unilateral guide cannula (Synaptech) aimed at the NAcSh (anteroposterior: $1.2 \mathrm{~mm}$
Table 1. Group assignments, drug treatment, target site, and total animal number $^{a}$

\begin{tabular}{llllc}
\hline Experiment & Group & Drug & Target & Completed $^{b}$ \\
\hline Intravenous cocaine & Control & aCSF & VTA & $13(17)$ \\
self-administration & Control & CP 50 & VTA & $3(3)$ \\
& Control & CP 500 & VTA & $7(7)$ \\
& Control & A2B 100 & VTA & $3(3)$ \\
& Control & A2B 1000 & VTA & $9(12)$ \\
& Stress & aCSF & VTA & $11(18)$ \\
& Stress & CP 50 & VTA & $8(9)$ \\
& Stress & CP 500 & VTA & $10(11)$ \\
& Stress & A2B 100 & VTA & $8(10)$ \\
& Stress & A2B 1000 & VTA & $13(15)$ \\
& Control & aCSF & VTA/NACSh & 5 \\
& Control & CP 500 & VTA/NACSh & 5 \\
& Control & A2B 1000 & VTA/NACSh & 5 \\
& Stress & aCSF & VTA/NACSh & 5 \\
& Stress & CP 50 & VTA/NACSh & 7 \\
& Stress & CP 500 & VTA/NACSh & 5 \\
& Stress & A2B 100 & VTA/NACSh & 4 \\
& Stress & A2B 1000 & VTA/NACSh & 6 \\
\hline
\end{tabular}

${ }^{a}$ Data represent all the treatment groups and the total number of rats in each experiment.

${ }^{b}$ The number within parentheses are the animals that completed the behavioral sensitization phase of the experiment but did not complete the cocaine self-administration phase because of loss of patency, sickness, or fulfillment of responding requirements.

from bregma; mediolateral: $1.1 \mathrm{~mm}$ from midline; dorsoventral: -5.8 $\mathrm{mm}$ from dura). Rats were allowed to recover for at least $5 \mathrm{~d}$ before the first microinjection.

\section{Microinjection and social defeat}

All rats were microinjected with CP ( 50 or $500 \mathrm{ng} / \mathrm{side}$ ), A2B (100 or 1000 ng/side), or aCSF on experimental days 1, 4, 7, and 10 (Fig. 1). After infusion, injectors were left in place for one additional minute to prevent backflow and allow for diffusion; then the rats were returned to their home cages. Ten minutes after the start of the microinjection, the social defeat proceeded as described previously (Covington et al., 2008; Boyson et al., 2011). Briefly, stressed rats were placed in a wire mesh protective cage inside a resident rat's home cage for $10 \mathrm{~min}$, after which the protective cage was removed and the fight began. The fight ended after 10 attack bites, $6 \mathrm{~s}$ of supine posture, or $5 \mathrm{~min}$ after the first attack bite, whichever came first. Latency to the first bite, number of bites, and total encounter duration were recorded. Immediately after the fight, rats were placed back in the protective enclosure in the resident's cage for an additional 10 

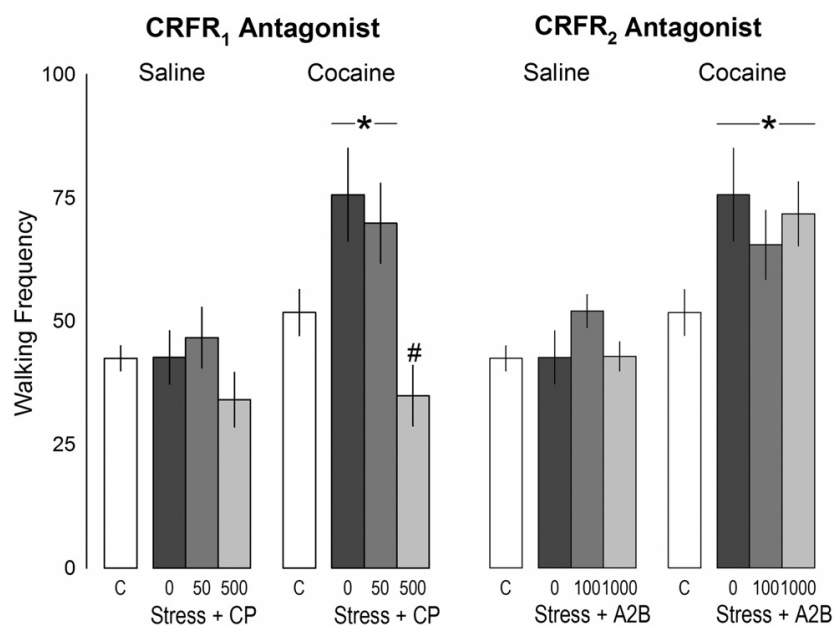

Figure 2. Intra-VTA microinjections of a $\mathrm{CRFR}_{1}(\mathrm{CP})$, but not $\mathrm{CRFR}_{2}(\mathrm{A2B})$ antagonist prevented stress-induced locomotor cross-sensitization to a cocaine challenge. Mean \pm SEM walking frequency during a saline challenge and a subsequent cocaine challenge ( $10 \mathrm{mg} / \mathrm{kg}$ i.p.) $10 \mathrm{~d}$ after the social defeat phase is portrayed. The graph is split into the treatment groups. Left bars represent CRFR $\mathrm{R}_{1}$ antagonist. Right bars represent CRFR antagonist. Left, Groups from left to right: $C$, nonstressed control aCSF, $n=17 ; 0$, stressed + aCSF, $n=18 ; 50$, stressed + CP 50 $\mathrm{ng} /$ side, $n=9 ; 500$, stressed + CP $500 \mathrm{ng} /$ side, $n=11$. Right, Groups from left to right: $C$, nonstressed control aCSF, $n=17 ; 0$, stressed + aCSF, $n=18 ; 100$, stressed + A2B 100 $\mathrm{ng} / \mathrm{side}, n=10 ; 1000$, stressed + A2B $1000 \mathrm{ng} /$ side, $n=15$. aCSF treatment groups are the same in both plots. Controls with pretreatment of $\mathrm{CP}$ and $\mathrm{A} 2 \mathrm{~B}$ are not represented but were incorporated into the statistical analyses (controls: CP $50 \mathrm{ng} / \mathrm{side}, n=3 ; C P 500 \mathrm{ng} / \mathrm{side}, n=7$; A2B $100 \mathrm{ng} / \mathrm{side}, n=3$; A2B $1000 \mathrm{ng} / \mathrm{side}, n=12)$. ${ }^{*} p<0.05$ from nonstressed aCSF. $\# p<$ 0.05 from stressed aCSF.

min of social threat, and subsequently returned to their home cage. Nonstressed control rats were microinjected in the same manner as defeated rats but were returned to their home cages after $1 \mathrm{~min}$ of diffusion.

\section{Locomotor sensitization testing}

Ten days after the last microinjection, all rats were challenged with an acute injection of a marginally effective dose of cocaine ( $10 \mathrm{mg} / \mathrm{kg}$, i.p.) to assess locomotor cross-sensitization. Rats were injected with saline (i.p.) once daily for $3 \mathrm{~d}$ before sensitization testing to ensure habituation to handling and injection. Sensitization testing occurred in the rat's home cage (Covington and Miczek, 2001). Rats were injected with saline, and 5 $\mathrm{min}$ later their behavior was recorded for $5 \mathrm{~min}$. Rats were then injected with cocaine and recorded for an additional 5 min immediately after the injection. Video recordings were analyzed by a reliable observer (intraobserver reliability: $r>0.95$ ) for duration and frequency of rearing, walking, grooming, and immobility using a customized keyboard and computer software (Observer Video-Pro version 8.0, Noldus Information Technology). The dependent variable represented in Figure 2 is walking frequency, defined as the initiation of a forepaw movement.

\section{Intravenous cocaine self-administration}

Surgery. After locomotor sensitization testing, rats were implanted with a catheter (SILASTIC silicon tubing, Dow Corning, ID $0.63 \mathrm{~mm}$, OD 1.17 $\mathrm{mm})$ in the right jugular vein under ketamine $(100 \mathrm{mg} / \mathrm{kg})$ and xylazine $(6 \mathrm{mg} / \mathrm{kg})$ anesthesia. The catheter was passed subcutaneously through the back, exited through a small incision at the base of the neck, and was affixed to a small plastic pedestal (SAI Infusion Technologies) mounted inside a harness. Rats were allowed to recover for $5 \mathrm{~d}$ before being moved from their home cage to permanent housing in intravenous self-administration chambers. To ensure catheter patency, catheters were flushed with $0.2 \mathrm{ml}$ saline and $0.2 \mathrm{ml}$ heparinized saline $(20$ $\mathrm{IU} / \mathrm{ml}$ ) before each self-administration session, and $0.17 \mathrm{ml}$ pulses of saline were delivered every $30 \mathrm{~min}$, except during the daily selfadministration session.

Acquisition and stable FR 5 performance. Rats were allowed to freely self-administer cocaine $(0.75 \mathrm{mg} / \mathrm{kg} /$ infusion $)$ without a priming infu-
Table 2. Effects of social defeat stress on stable cocaine self-administration fixed ratio 5 (FR 5) rate (response/min) and progressive ratio (PR) infusions ${ }^{a}$

\begin{tabular}{llrll}
\hline Group & Drug & $\mathrm{n}$ & $\mathrm{FR} 5$ & $\mathrm{PR}^{b}$ \\
\hline Control & aCSF & 13 & $0.64 \pm 0.05$ & $8.96 \pm 0.48$ \\
Control & CP50 & 7 & $0.90 \pm 0.14^{*}$ & $10.0 \pm 0.83$ \\
Control & CP 500 & 3 & $1.13 \pm 0.18^{*}$ & $10.9 \pm 0.29$ \\
Control & A2B 100 & 9 & $0.92 \pm 0.11$ & $11.0 \pm 0.80$ \\
Control & A2B 1000 & 3 & $0.71 \pm 0.11$ & $12.7 \pm 1.17$ \\
Stress & aCSF & 11 & $0.80 \pm 0.08$ & $10.7 \pm 0.69$ \\
Stress & CP 50 & 8 & $0.87 \pm 0.07$ & $11.9 \pm 0.52$ \\
Stress & CP 500 & 10 & $0.99 \pm 0.11$ & $9.75 \pm 0.67$ \\
Stress & A2B 100 & 8 & $0.93 \pm 0.11$ & $11.2 \pm 0.55$ \\
Stress & A2B 1000 & 13 & $0.77 \pm 0.06$ & $10.8 \pm 0.77$
\end{tabular}

${ }^{a}$ Data represent the mean \pm SEM of the last $3 \mathrm{~d}$ of stable FR 5 (response/min) rate on the active lever for cocaine delivery.

${ }^{b}$ The numbers represent the mean \pm SEM performance of progressive ratio infusions across the treatment groups. *Significant drug effect between aCSF and CP376395 groups $(p<0.05)$.

sion during daily self-administration sessions, which were signaled by a stimulus light. Two retractable levers were located on one wall of the home cage. Pressing the left lever (active) resulted in an intravenous cocaine infusion, followed by a $30 \mathrm{~s}$ time out period with the stimulus light off. Pressing the right lever (inactive) was neither reinforced nor punished, but presses were recorded. Each session terminated after 15 infusions or $5 \mathrm{~h}$ of access. Acquisition was defined as 2 consecutive days with 15 self-administered infusions. If rats did not achieve this requirement within the first $2 \mathrm{~d}$ of cocaine access, they were behaviorally shaped on the third day; because of this, differences in acquisition rates cannot be assessed. Behavioral shaping consisted of placing female urine or palatable food on the active lever to attract the animals. Levers were wiped clean and behavioral shaping terminated once the rats reliably selfadministered cocaine. After completing 2 consecutive days of 15 infusions under FR 1 in $<5$ h, the FR schedule of cocaine reinforcement progressively increased from 1 until every fifth lever press resulted in an intravenous cocaine infusion (FR $1 \rightarrow$ FR 5). To achieve stable responding across all groups, rats were maintained on an FR 5 schedule to earn 15 infusions for 3-5 consecutive days. All rats completing a stable FR 5 performance session pressed the active lever 75 times to receive 15 infusions. The last $3 \mathrm{~d}$ of stable FR 5 performance alternated between progressive ratio sessions, thus occurring every other day. These last $3 \mathrm{~d}$ were averaged to obtain a dependent variable for the response rate (response/ min) across treatment groups (Table 2).

Progressive ratio. Rats were tested under a progressive ratio schedule (PR, $0.3 \mathrm{mg} / \mathrm{kg} /$ infusion), in which they must respond with an increasing number of lever presses for cocaine reinforcement. The progressive response increment was as follows: 1, 2, 4, 6, 9, 12, 15, 20, 25, 32, 40, 50, 62, 77, 95, 118, 145, and 178 (Richardson and Roberts, 1996). Sessions terminated when 60 min elapsed without a cocaine infusion, and the number of infusions delivered, the "break point," was recorded. Three PR sessions were conducted, alternating with stable FR 5 performance sessions, and the average number of cocaine infusions delivered over the three sessions was used as the dependent variable across treatment groups (Table 2).

Twenty-four hour "binge." After the three alternating sessions of PR and FR 5, rats were given one more day of limited access to cocaine (FR 5 , $0.75 \mathrm{mg} / \mathrm{kg} /$ infusion, 15 infusions). The following day, rats were given unlimited access to cocaine (FR 5, $0.3 \mathrm{mg} / \mathrm{kg} /$ infusion) in a $24 \mathrm{~h}$ "binge." The total number of cocaine infusions was the dependent variable across treatment groups. After the completion of the "binge," catheter patency was checked by injection of propofol $(10 \mathrm{mg} / \mathrm{ml}, 0.2 \mathrm{ml})$ and rats were then killed and their brains removed for histological verification of injector sites.

\section{In vivo microdialysis}

A separate cohort of rats underwent in vivo microdialysis of the NAcSh to assess the dopaminergic response to acute cocaine (10 mg/kg, i.p.) $10 \mathrm{~d}$ after the last defeat (see Fig. 1) as previously described (Miczek et al., 2011; Shimamoto et al., 2011; Holly et al., 2012). As with the locomotor 
sensitization experiment, rats were injected with saline (intraperitoneal) once per day for $3 \mathrm{~d}$ before testing to habituate them to handling and injection. The day before sample collection, rats were briefly anesthetized with isoflurane and the microdialysis cannula stylet replaced with a $2 \mathrm{~mm}$ active membrane probe (Synaptech) connected to a syringe filled with aCSF (CMA Microdialysis). The infusion rate was set to $0.5 \mu \mathrm{l} / \mathrm{min}$ overnight and increased to $1.5 \mu \mathrm{l} / \mathrm{min} 30 \mathrm{~min}$ before sample collection the next day.

Samples were collected every $10 \mathrm{~min}$ using a refrigerated fraction collector (CMA 142, CMA Microdialysis) in vials with $5 \mu$ l antioxidant (20 mM phosphate buffer containing $25 \mathrm{~mm}$ EDTA-2 NA and $0.5 \mathrm{~mm}$ ascorbic acid, $\mathrm{pH}$ 3.5). Tonic levels of DA were assessed in 5 baseline samples, followed by intraperitoneal injections of saline (at $55 \mathrm{~min}$ ) and cocaine $(10 \mathrm{mg} / \mathrm{kg}$ at $75 \mathrm{~min})$. Samples were collected for an additional $115 \mathrm{~min}$ after the cocaine injection to assess the time course of dopaminergic changes.

DA was analyzed using high-performance liquid chromatography, which consisted of an LC10-AD pump (Shimadzu) and manual injector (model 7,125, Rheodyne) with a $100 \mu$ l sample loop. Mobile phase composition was $150 \mathrm{~mm}$ ammonium acetate, $50 \mathrm{~mm}$ citric acid, $27 \mu \mathrm{M}$ EDTA, $10 \%$ methanol, and $1 \%$ acetonitrile, with $\mathrm{pH}$ adjusted to 4.6 and flow rate set to $0.2 \mathrm{ml} / \mathrm{min}$. A cation-exchange column (CAPCELL PAK, $1.5 \times 250 \mathrm{~mm}, 5 \mu \mathrm{m} \mathrm{ID}$, Shiseido) with temperature set to $30^{\circ} \mathrm{C}$ was used to separate monoamines, which were then analyzed using an electrochemical detection system (DECADE II, Antec Leyden BV). DA concentrations were calculated using a standard curve with known amounts of monoamines in a range of $1.875-18.75 \mathrm{pg}$, and the limit of detection for DA was $0.21 \mathrm{pg}$.

\section{Histology}

After the completion of the self-administration or microdialysis experiments, rats were deeply anesthetized with pentobarbital (100 mg/kg, i.p.) and underwent transcardial perfusion with saline and 4\% PFA. Brain tissue was preserved in 4\% PFA and then sectioned into $50 \mu \mathrm{m}$ slices using a cryostat (Leica CM1900). Slices were mounted on gelatin-coated slides and then were stained with cresyl violet to examine exact cannula or probe placement using light microscopy (Fig. 3).

\section{Drugs}

CP376395 and Astressin ${ }_{2}$-B (Tocris Bioscience) were prepared in aCSF. Higher doses were selected based on previous in vivo studies (Henry et al., 2006; Blacktop et al., 2011), with lower doses chosen to examine doseresponse. Cocaine hydrochloride was obtained from the Research Technology Branch of the National Institute on Drug Abuse (Rockville, MD) and dissolved in sterile $0.9 \%$ saline; doses were selected based on previous work in our laboratory (Boyson et al., 2011; Holly et al., 2012).

\section{Statistical analysis}

To assess locomotor sensitization, walk frequency was analyzed by split plot factor three-way repeated measures ANOVA (SAS, SAS Institute) followed by a priori driven one-way ANOVA (Sigma Plot version 11.0, Systat Software) to evaluate the effect of pretreatment drugs and doses within the stressed group and overall effect of stress within the CP and A2B-pretreated animals. To analyze dopaminergic sensitization, percentage change from individuals' baseline DA was used in place of pmol concentration to reduce intragroup and intergroup variability. A priori two-way ANOVAs were used to assess the effects of cocaine across the samples within each stress group, the effect of social defeat stress across both aCSF pretreated groups, and the effect of $\mathrm{CP}$ and $\mathrm{A} 2 \mathrm{~B}$ pretreatment within each stress condition. For cocaine self-administration, two-way ANOVAs were used to assess FR response rate, PR "breakpoint," and total "binge" infusions. All post hoc ANOVAs were followed by HolmSidak corrections for multiple comparisons.

\section{Results}

\section{Locomotor cross-sensitization}

Intra-VTA $\mathrm{CRFR}_{1}$ antagonist dose-dependently prevented stress-induced locomotor sensitization to an acute cocaine challenge (10 mg/kg, i.p.), whereas $\mathrm{CRFR}_{2}$ antagonist did not (Fig. 2).
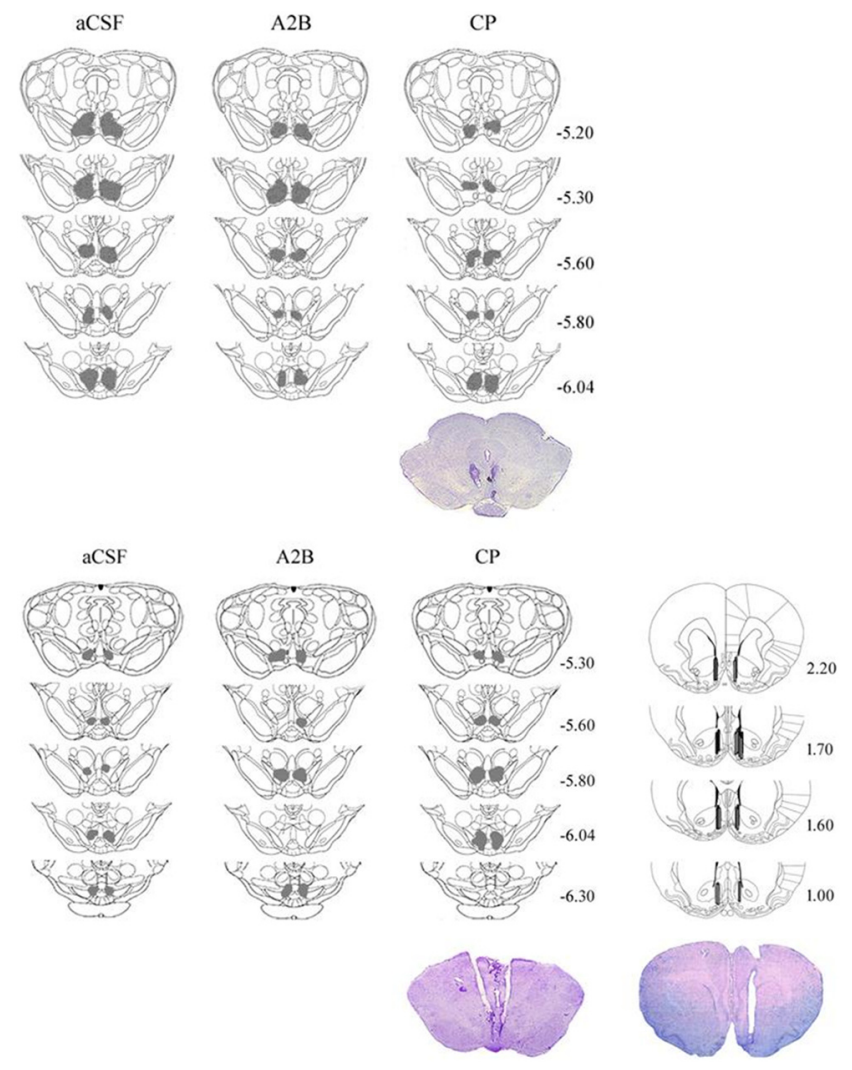

Figure 3. Top, Placements of intra-VTA bilateral cannula for the cocaine self-administration study. Each figure corresponds to coronal sections of the rat brain from -5.2 to $-6.30 \mathrm{~mm}$ from bregma. The gray shaded region represents the average location of bilateral cannula tips (top and bottom). From left to right, Columns depict average placements for rats receiving aCSF $(n=35), \mathrm{A} 2 \mathrm{~B}(n=40)$, and $\mathrm{CP}(n=30)$. Bottom, Placements of intra-VTA bilateral cannula for the in vivo microdialysis study. From left to right, Columns depict average placements for rats receiving aCSF $(n=10), \mathrm{A} 2 \mathrm{~B}(n=15)$, and $\mathrm{CP}(n=17)$, and with the last column depicting accurate placements in the NACSh. Bottom schematic, Photomicrograph of an intra-VTA and nucleus accumbens site.

Overall, cocaine significantly increased the walking frequency in all groups (Fig. 2: $\mathrm{CP} F_{(1,60)}=22.42 ; p<0.0001$; A2B; $F_{(1,70)}=$ 33.99; $p<0.0001)$. There was a three-way interaction for the rats pretreated with $\mathrm{CRFR}_{1}$ antagonist before social stress (pretreatment drug dose $\times$ stress condition $\times$ cocaine effect; $F_{(2,60)}=$ $6.41 ; p=0.0030)$. There was also an overall pretreatment drug effect within the stressed group (one-way ANOVA: $F_{(2,35)}=$ 5.879; $p=0.006$ ). Post hoc tests showed that the high dose of a $\mathrm{CRFR}_{1}$ antagonist (CP $500 \mathrm{ng} /$ side) prevented stress-induced locomotor sensitization, whereas the lower dose (CP $50 \mathrm{ng} / \mathrm{side})$ was less effective $(t=3.336, p=0.006 ; t=0.443, p=0.660)$ compared with the aCSF stress group. Neither dose of $\mathrm{CRFR}_{2}$ antagonist (A2B, 100 or $1000 \mathrm{ng} /$ side) prevented stress-induced locomotor sensitization when injected into the VTA before social defeat; rather, there was only an overall stress effect compared with the nonstressed group (two-way ANOVA: $F_{(1,70)}=4.664$; $p=0.034)$. Additionally, there were significant three-way interactions (pretreatment drug dose $\times$ stress condition $\times$ cocaine effect) for immobility $\left(\mathrm{CP}: F_{(1,60)}=8.40, p=0.0052\right.$; $\mathrm{A} 2 \mathrm{~B}$ : $n$ ot significant $)$ and rearing $\left(\mathrm{CP}: F_{(1,60)}=6.27, p=0.0150\right.$; $\mathrm{A} 2 \mathrm{~B}$ : not significant) frequencies, with no such interactions for grooming frequency or walking, immobility, rearing, or grooming duration (Table 3). 
Table 3. Effects of social defeat stress on frequency and duration of immobility, grooming, and rearing behaviors during an acute cocaine injection ${ }^{a}$

\begin{tabular}{|c|c|c|c|c|c|c|c|c|c|c|}
\hline \multirow[b]{2}{*}{ Group } & \multirow[b]{2}{*}{ Drug } & \multirow[b]{2}{*}{$n$} & \multicolumn{2}{|l|}{ Immobility* } & \multicolumn{2}{|l|}{ Grooming } & \multicolumn{2}{|l|}{ Rearing* } & \multicolumn{2}{|l|}{ Walking $^{b}$} \\
\hline & & & Saline & Cocaine & Saline & Cocaine & Saline & Cocaine & Saline & Cocaine \\
\hline \multicolumn{11}{|c|}{$\begin{array}{l}\text { Effects of social defeat } \\
\text { stress on frequency }\end{array}$} \\
\hline Control & $\mathrm{aCSF}$ & 17 & $43.11 \pm 1.94$ & $53.00 \pm 4.27$ & $2.74 \pm 0.59$ & $2.17 \pm 0.47$ & $20.68 \pm 1.37$ & $14.89 \pm 2.17$ & $42.47 \pm 2.54$ & $51.78 \pm 4.66$ \\
\hline Control & CP 50 & 3 & $57.00 \pm 5.51$ & $47.67 \pm 7.96$ & $0.67 \pm 0.67$ & $1.33 \pm 0.67$ & $22.67 \pm 6.17$ & $23.33 \pm 12.91$ & $57.33 \pm 4.17$ & $57.00 \pm 14.36$ \\
\hline Control & CP 500 & 7 & $30.57 \pm 5.28$ & $55.00 \pm 13.63$ & $3.14 \pm 0.94$ & $2.00 \pm 0.82$ & $11.00 \pm 2.80$ & $12.00 \pm 4.87$ & $27.29 \pm 7.89$ & $51.86 \pm 14.76$ \\
\hline Control & A2B 100 & 3 & $46.00 \pm 3.79$ & $56.67 \pm 2.03$ & $4.67 \pm 1.86$ & $2.00 \pm 0.58$ & $23.67 \pm 6.33$ & $20.00 \pm 7.23$ & $52.67 \pm 8.74$ & $58.33 \pm 5.49$ \\
\hline Control & A2B 1000 & 12 & $52.17 \pm 2.38$ & $60.75 \pm 5.62$ & $1.67 \pm 0.40$ & $1.08 \pm 0.29$ & $15.75 \pm 1.13$ & $14.33 \pm 4.61$ & $42.92 \pm 1.97$ & $54.58 \pm 5.05$ \\
\hline Stress & $\mathrm{aCSF}$ & 18 & $41.61 \pm 3.29$ & $64.88 \pm 6.23$ & $3.11 \pm 0.63$ & $3.27 \pm 0.86$ & $16.11 \pm 1.92$ & $19.06 \pm 4.22$ & $42.67 \pm 5.40$ & $75.67 \pm 9.36$ \\
\hline Stress & CP 50 & 9 & $46.67 \pm 6.25$ & $68.56 \pm 6.94$ & $4.22 \pm 1.02$ & $3.00 \pm 0.85$ & $19.67 \pm 3.30$ & $19.56 \pm 4.47$ & $46.67 \pm 6.13$ & $69.89 \pm 8.11$ \\
\hline Stress & CP 500 & 11 & $38.64 \pm 4.88$ & $39.09 \pm 5.86$ & $2.82 \pm 1.09$ & $3.27 \pm 0.81$ & $17.73 \pm 2.65$ & $10.64 \pm 1.53$ & $34.09 \pm 5.52$ & $34.91 \pm 6.12$ \\
\hline Stress & $\mathrm{A} 2 \mathrm{~B} 100$ & 10 & $52.70 \pm 2.36$ & $64.00 \pm 5.46$ & $2.20 \pm 0.47$ & $2.70 \pm 0.65$ & $23.70 \pm 3.22$ & $14.80 \pm 4.99$ & $52.10 \pm 3.31$ & $65.50 \pm 7.00$ \\
\hline Stress & A2B 1000 & 15 & $53.8 \pm 2.79$ & $81.26 \pm 6.54$ & $2.00 \pm 0.37$ & $2.53 \pm 0.69$ & $19.6 \pm 1.74$ & $15.67 \pm 3.58$ & $42.87 \pm 2.96$ & $71.80 \pm 6.52$ \\
\hline \multicolumn{11}{|c|}{$\begin{array}{l}\text { Effects of social defeat } \\
\text { stress on duration }\end{array}$} \\
\hline Control & $\mathrm{aCSF}$ & 17 & $141.46 \pm 7.32$ & $177.61 \pm 12.11$ & $24.04 \pm 6.85$ & $8.47 \pm 1.91$ & $73.20 \pm 6.23$ & $33.40 \pm 5.96$ & $43.90 \pm 3.31$ & $63.28 \pm 10.62$ \\
\hline Control & CP 50 & 3 & $148.56 \pm 17.11$ & $115.52 \pm 41.49$ & $4.10 \pm 4.10$ & $9.31 \pm 7.88$ & $70.49 \pm 20.35$ & $40.39 \pm 15.20$ & $73.15 \pm 4.35$ & $130.73 \pm 25.19$ \\
\hline Control & CP 500 & 7 & $181.54 \pm 10.72$ & $170.28 \pm 7.31$ & $30.48 \pm 9.22$ & $26.58 \pm 13.15$ & $37.78 \pm 8.45$ & $26.53 \pm 7.52$ & $24.33 \pm 4.78$ & $54.00 \pm 17.20$ \\
\hline Control & $\mathrm{A} 2 \mathrm{~B} 100$ & 3 & $121.14 \pm 9.80$ & $152.98 \pm 20.25$ & $37.23 \pm 18.27$ & $22.32 \pm 5.96$ & $85.22 \pm 21.06$ & $46.62 \pm 22.12$ & $51.26 \pm 5.56$ & $74.25 \pm 6.83$ \\
\hline Control & A2B 1000 & 12 & $169.56 \pm 6.85$ & $191.76 \pm 11.77$ & $23.65 \pm 7.07$ & $13.28 \pm 5.71$ & $54.21 \pm 4.72$ & $27.35 \pm 7.91$ & $41.39 \pm 4.41$ & $57.25 \pm 7.96$ \\
\hline Stress & $\mathrm{aCSF}$ & 18 & $169.44 \pm 8.55$ & $164.62 \pm 13.14$ & $29.51 \pm 8.51$ & $33.71 \pm 13.95$ & $47.31 \pm 5.88$ & $25.69 \pm 5.47$ & $45.94 \pm 4.76$ & $75.62 \pm 7.56$ \\
\hline Stress & CP 50 & 9 & $146.97 \pm 22.23$ & $147.93 \pm 10.94$ & $18.92 \pm 5.08$ & $20.61 \pm 8.13$ & $69.52 \pm 14.66$ & $28.47 \pm 4.48$ & $60.79 \pm 8.22$ & $98.23 \pm 12.22$ \\
\hline Stress & CP 500 & 11 & $166.09 \pm 7.44$ & $168.98 \pm 13.34$ & $20.57 \pm 7.13$ & $40.52 \pm 12.04$ & $53.76 \pm 5.57$ & $30.55 \pm 5.19$ & $34.96 \pm 4.70$ & $38.69 \pm 7.38$ \\
\hline Stress & $\mathrm{A} 2 \mathrm{~B} 100$ & 10 & $148.38 \pm 10.87$ & $173.46 \pm 10.26$ & $28.61 \pm 10.74$ & $23.39 \pm 5.65$ & $73.73 \pm 9.31$ & $24.23 \pm 7.94$ & $45.77 \pm 2.14$ & $74.30 \pm 7.64$ \\
\hline Stress & A2B 1000 & 15 & $147.34 \pm 8.03$ & $175.19 \pm 6.50$ & $34.61 \pm 9.34$ & $16.29 \pm 6.73$ & $68.29 \pm 8.45$ & $26.84 \pm 6.60$ & $33.90 \pm 2.12$ & $71.80 \pm 6.70$ \\
\hline
\end{tabular}

${ }^{a}$ Data are mean \pm SEM during an acute injection of saline followed by an acute cocaine injection (10 mg/kg, ip).

${ }^{b}$ Walking frequency is represented in Figure 2.

*Significant interaction $(p<0.05)$.

\section{Intravenous cocaine self-administration}

Acquisition, stable FR 5 performance and progressive ratio

All rats acquired cocaine self-administration within $7 \mathrm{~d}$, and reliably self-administered cocaine, earning 15 infusions in $<5 \mathrm{~h}$ on an FR 5 schedule, within $15 \mathrm{~d}$ of completing acquisition. FR 5 performance rate was defined as the average of the final three days of stable responding before the "binge." During stable FR 5 performance, there was an overall drug effect (pretreatment drug dose) on response rate (two-way ANOVA: $F_{(2,46)}=4.926 ; p=$ 0.012 ) when comparing aCSF versus $C P$ treatment. Overall, there were no statistically significant effects for the PR "break point" during cocaine self-administration across groups (Table 2).

Twenty-four hour cocaine "binge"

$\mathrm{CRFR}_{1}$ antagonist microinjected into the VTA before social defeat stress significantly and dose-dependently prevented the longterm effects of stress-escalated cocaine taking during a $24 \mathrm{~h}$ "binge." Overall, there was a significant drug effect for the rats pretreated with $\mathrm{CRFR}_{1}$ antagonist before social stress (pretreatment drug dose; two-way ANOVA: $\left.F_{(2,46)}=4.282 ; p=0.020\right)$ and a significant interaction (pretreatment drug dose $X$ stress condition; two-way ANOVA: $\left.F_{(2,46)}=4.576 ; p=0.015\right)$. Post hoc analysis showed a significant stress effect within the aCSF-treated rats (aCSF nonstressed vs aCSF-stressed: $t=3.819, p<0.001$ ). More importantly, post hoc analysis revealed that only the high dose of CP376395 (500 ng/side) prevented escalated cocaine taking during a $24 \mathrm{~h}$ "binge" (stressed group, aCSF vs CP 500: $t=$ 2.741, $p=0.026$ ), whereas the lower dose of CP376395 (50 ng/ side) did not (stressed group, aCSF vs CP 50: $t=0.756, p=0.453$; Fig. 4, top right).

$\mathrm{CRFR}_{2}$ antagonist microinjected into the VTA before social defeat stress also significantly and dose-dependently prevented stress-escalated cocaine taking during a $24 \mathrm{~h}$ "binge." Overall, there was a significant interaction for the rats pretreated with
$\mathrm{CRFR}_{2}$ antagonist before social stress (pretreatment drug dose $\times$ stress condition; two-way ANOVA: $\left.F_{(2,51)}=3.907 ; p=0.026\right)$. Post hoc analyses revealed a significant drug effect on total cocaine intake in $24 \mathrm{~h}$ in the rats exposed to stress and pretreated with the high dose (1000 ng/side) of A2B (stressed group, aCSF vs A2B 1000: $t=3.016, p=0.012$ ), whereas the low dose only showed a prevention trend compared with the aCSF-stressed group (stressed group, aCSF vs A2B 100: $t=1.833, p=0.140$; Fig. 4, bottom right).

For the cumulative cocaine infusions (Fig. 4, left: top and bottom), the same two-way ANOVA was conducted at the $24 \mathrm{~h}$ time point and thus revealed identical statistics as described above. Missed placements observed in pretreatment stress condition were suggestive but not definitive. Two rats pretreated with CP $(500 \mathrm{ng} / \mathrm{side})$ before stress that had missed microinjection placements averaged $394.5 \pm 20.5$ infusions of cocaine during a $24 \mathrm{~h}$ "binge." One rat pretreated with A2B (1000 ng/side) before stress that had a missed placement obtained 162 infusions of cocaine during a $24 \mathrm{~h}$ "binge." There were no missed placements for rats receiving either $\mathrm{CP}$ (50 ng/side) or A2B (100 ng/side) before stress.

\section{In vivo microdialysis}

There was no difference in average tonic DA (pmol) across treatment or stress groups (represented as mean pmol/15 $\mu$ l sample \pm SEM: stressed aCSF $1.773 \pm 0.385, n=5$; stressed CP $50 \mathrm{ng} / \mathrm{side}$ $1.054 \pm 0.148, n=7$; stressed CP $500 \mathrm{ng} /$ side $3.263 \pm 0.845, n=$ 6; stressed A2B $100 \mathrm{ng} /$ side $1.874 \pm 0.536, n=4$; stressed A2B $1000 \mathrm{ng} /$ side $2.198 \pm 0.913, n=5$; nonstressed aCSF $3.416 \pm$ 1.436, $n=5$; nonstressed CP $500 \mathrm{ng} /$ side $4.384 \pm 1.756, n=5$; nonstressed A2B $1000 \mathrm{ng} /$ side $1.548 \pm 0.242, n=4)$. Three-way repeated-measures ANOVAs with factors of drug pretreatment, stress condition, and sample revealed no significant difference 

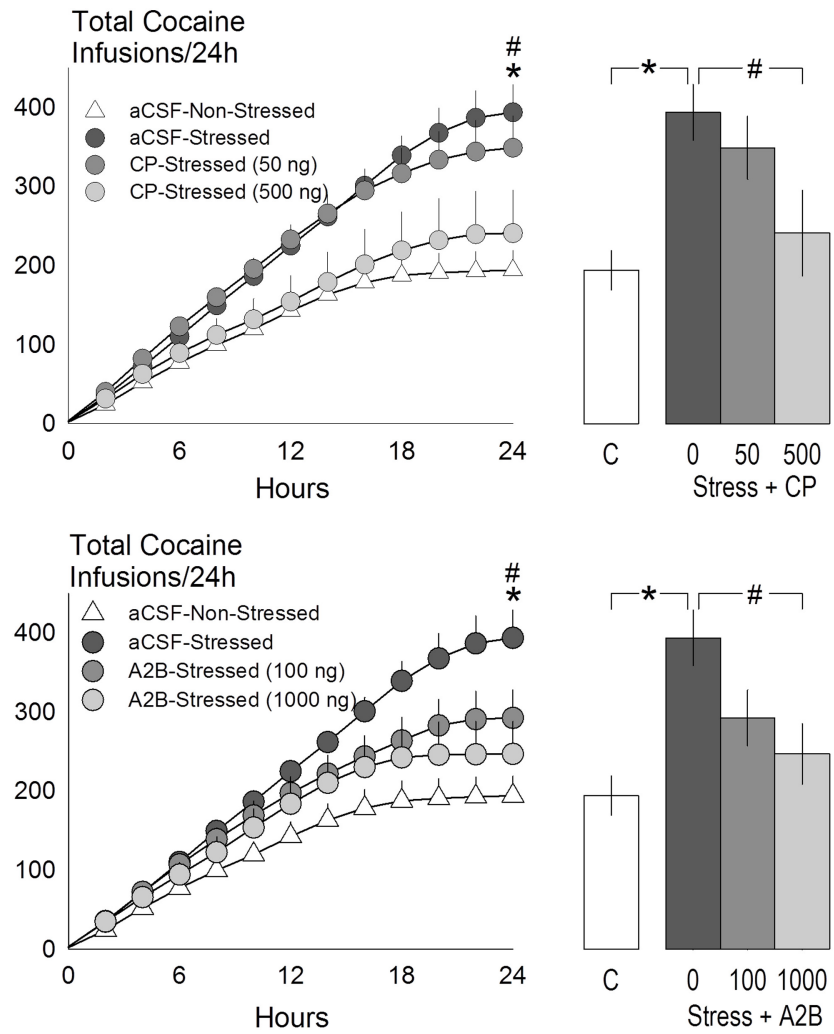

Figure 4. Dose-dependent effects of intra-VTA infusions of (top) $\mathrm{CRFR}_{1}(\mathrm{CP})$ and (bottom) $\mathrm{CRFR}_{2}(\mathrm{~A} 2 \mathrm{~B})$ antagonists during intermittent social defeat on subsequent cocaine taking behaviors during a $24 \mathrm{~h}$ "binge." Top left, Time course in which the nonstressed rats pretreated with aCSF $(n=13)$ and the stressed rats pretreated with aCSF $(n=11)$ or CRFR $_{1}$ antagonist (CP 50 $\mathrm{ng} / \mathrm{side}, n=8$; (P $500 \mathrm{ng} / \mathrm{side}, n=10)$ self-administered cocaine during a $24 \mathrm{~h}$ "binge." Top right, Mean \pm SEM total number of cocaine infusions self-administered during a $24 \mathrm{~h}$ "binge." Groups from left to right: $C$, control aCSF, $n=13 ; 0$, Stress + aCSF, $n=11 ; 50$, Stress + CP 50 $\mathrm{ng} / \mathrm{side}, n=8 ; 500$, Stress + CP $500 \mathrm{ng} / \mathrm{side}, n=10$. Bottom left, Time course in which the nonstressed rats pretreated with aCSF $(n=13)$ and the stressed rats pretreated with aCSF $(n=$ 11) or $\mathrm{CRFR}_{2}$ antagonist ( $\mathrm{A} 2 \mathrm{~B} 100 \mathrm{ng} / \mathrm{side}, n=8 ; \mathrm{A} 2 \mathrm{~B} 1000 \mathrm{ng} / \mathrm{side}, n=13$ ) self-administered cocaine during a $24 \mathrm{~h}$ "binge." Bottom right, Mean \pm SEM total number of cocaine infusions self-administered during a $24 \mathrm{~h}$ "binge." Groups from left to right, Nonstressed control aCSF, $n=13 ; 0$, stressed + aCSF, $n=11 ; 100$, stressed + A2B $100 \mathrm{ng} /$ side, $n=8 ; 1000$, stressed + $\mathrm{A} 2 \mathrm{~B} 1000 \mathrm{ng} / \mathrm{side}, n=13$. The aCSF-treated rats in both conditions are identical for top and bottom. Controls for pretreatment of $C P$ and $A 2 B$ are not represented in the graph but were incorporated into the statistical analyses (nonstressed controls: CP $50 \mathrm{ng} / \mathrm{side}, n=3 ;$ CP 500 $\mathrm{ng} / \mathrm{side}, n=7 ; \mathrm{A} 2 \mathrm{~B} 100 \mathrm{ng} / \mathrm{side}, n=3 ; \mathrm{A} 2 \mathrm{~B} 1000 \mathrm{ng} / \mathrm{side}, n=9)$. ${ }^{*} p<0.05$ versus nonstressed aCSF group. \#p $<0.05$ from stressed aCSF group.

between the five baseline samples and the postsaline injection sample, as well as no significant difference between baseline samples and all samples taken after 65 min postcocaine injection. Therefore, only samples from the saline injection until $65 \mathrm{~min}$ after cocaine were included in subsequent analyses. Intermittent social defeat stress resulted in dopaminergic cross-sensitization to cocaine, which was prevented by both CRFR ${ }_{1}$ and $\mathrm{CRFR}_{2}$ antagonism before social defeat stress. Overall, three-way repeatedmeasures ANOVA revealed a significant effect of drug pretreatment $\left(F_{(4,33)}=6.27, p<0.001\right)$ and sample $\left(F_{(7,231)}=23.74, p<0.0001\right.$, Fig. 4, top). Significant drug pretreatment $\times$ stress condition $\left.F_{(2,33)}=3.78, p=0.0333\right)$, drug pretreatment $\times$ sample $\left(F_{(28,231)}=\right.$ $4.51, p<0.0001)$ interactions were observed, although there was no drug pretreatment $\times$ stress condition $\times$ sample interaction $\left(F_{(14,231)}=1.30, p=0.2089\right)$. All animals with accurate NAcSh microdialysis cannula placements also had accurate intra-VTA microinjection cannula placements (Fig. 3), so no analysis of DA in animals with placements outside of the VTA was possible.
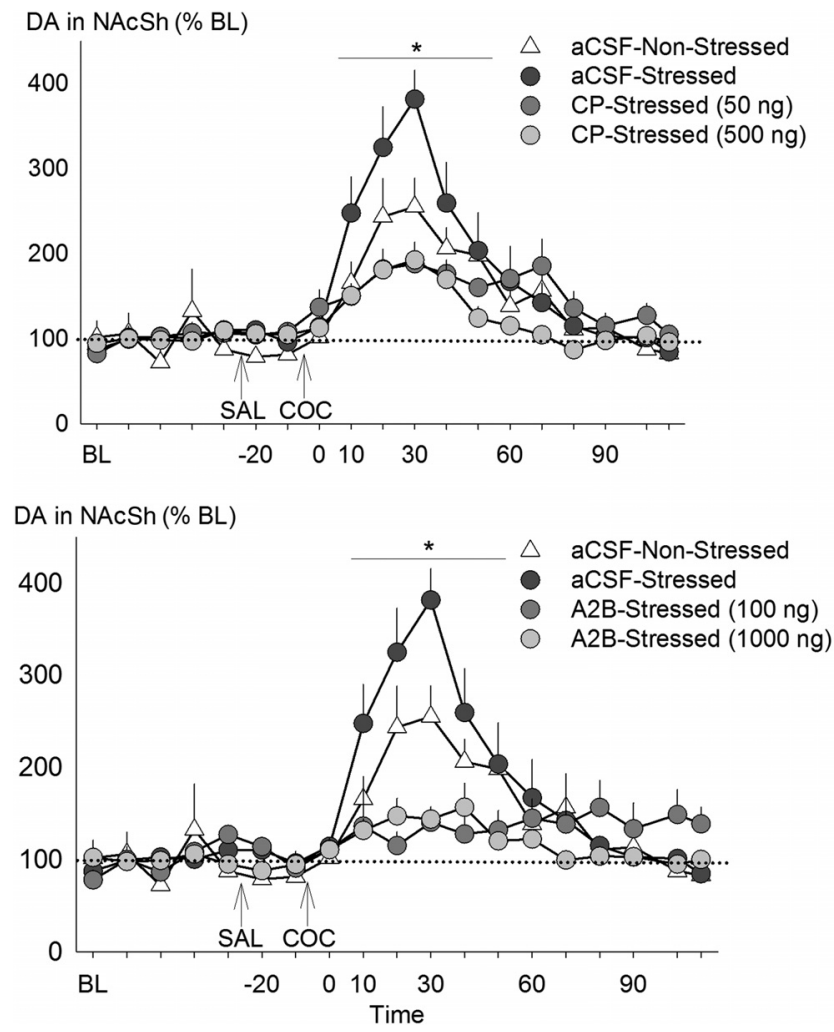

Figure 5. DA in the NACSh in response to saline and cocaine ( $10 \mathrm{mg} / \mathrm{kg}$, i.p.) in animals pretreated with (top) $\mathrm{CRFR}_{1}$ antagonist CP or (bottom) $\mathrm{CRFR}_{2}$ antagonist $A 2 B$ before social defeat stress. Top, Mean \pm SEM percentage change from baseline of DA in the NAcSh in nonstressed controls pretreated with aCSF $(n=5)$ and rats pretreated with aCSF $(n=5)$ or CP (50 $\mathrm{ng} / \mathrm{side}, n=7 ; 500 \mathrm{ng} / \mathrm{side}, n=5$ ) before social defeat stress in response to saline (SAL) and cocaine (COC). Bottom, Mean \pm SEM percentage change from baseline of DA in the NACSH in nonstressed controls pretreated with aCSF $(n=5)$ and rats pretreated with aCSF $(n=5)$ or A2B ( $100 \mathrm{ng} / \mathrm{side}, n=4 ; 1000 \mathrm{ng} / \mathrm{side}, n=6$ ) before social defeat stress in response to SAL and COC. Stressed and nonstressed rats pretreated with aCSF are the same for both figures. ${ }^{*} p<$ 0.05 versus nonstressed aCSF.

\section{Effect of cocaine}

Post hoc analysis of two-way repeated-measures ANOVA with Holm-Sidak corrections for multiple comparisons revealed that nonstressed rats pretreated with aCSF or A2B exhibited increased extracellular DA 25-55 min after cocaine injection $(p<0.018$, Fig. 5), whereas DA levels did not significantly change from baseline in nonstressed rats pretreated with CP. In stressed animals, extracellular NAcSh DA was significantly increased from baseline within the aCSF and CP pretreated animals, although the time course varied across groups. Stressed aCSF animals showed a prolonged elevation in accumbal DA (25-55 min after injection, $p<0.001$; Fig. 5) compared with those pretreated with CP (CP 50: 25-35 min, $p<0.05$; CP 500: 35 min, $p<0.05$; Fig. 5, top). Cocaine did not result in significant change from baseline within stressed animals pretreated with either dose of A2B (Fig. 5, bottom).

\section{Effect of social defeat stress}

Intermittent social defeat stress resulted in dopaminergic crosssensitization to cocaine. Within aCSF-treated animals, stressed rats showed significantly higher extracellular DA concentrations than nonstressed controls $15-35$ min after cocaine $(p<0.041$, Fig. 5), as demonstrated by post hoc analysis of two-way repeatedmeasures ANOVA with Holm-Sidak corrections for multiple comparisons. 


\section{Effect of $C P$ and $A 2 B$ pretreatment}

Both CP and A2B pretreatment before social defeat prevented the development of dopaminergic cross-sensitization to cocaine as assessed through DA release. Stressed animals showed significant effects of drug pretreatment $\left(F_{(4,154)}=6.518, p=0.001\right)$, sample $\left(F_{(7,154)}=16.439, p<0.001\right)$, and drug pretreatment $\times$ sample interaction $\left(F_{(28,154)}=4.135, p<0.001\right)$, with DA in aCSFpretreated animals significantly higher than $\mathrm{CP}$-pretreated animals after cocaine injection (CP 50: Holm-Sidak $t=3.166, p=$ 0.031; CP 500: Holm-Sidak $t=3.875, p=0.007$ ) and A2B (A2B 100: Holm-Sidak $t=4.046, p=0.005$; A2B 1000: Holm-Sidak $t=4.450, p=0.002$ ) and no difference between dopaminergic response to cocaine among the two drugs (Fig. 5, top and bottom). DA was significantly attenuated by pretreatment of all doses of both drugs $15-45$ min after cocaine injection $(p<0.05)$.

Within nonstressed animals, there was also a significant attenuation of the dopaminergic response to cocaine within the $\mathrm{CP}$ pretreated rats. There was a significant effect of sample $\left(F_{(7,77)}=\right.$ 14.503, $p<0.001)$ and drug pretreatment $\times$ sample interaction $\left(F_{(14,77)}=1.954, p=0.033\right)$, although there was no overall effect of drug. Nonstressed animals receiving CP pretreatment showed significantly reduced DA in response to cocaine compared with aCSF and A2B pretreated nonstressed controls from 35 to $55 \mathrm{~min}$ after cocaine $(p<0.045)$ (not graphically represented).

\section{Discussion}

The current study shows that $\mathrm{CRFR}_{1}$ and $\mathrm{CRFR}_{2}$ in the VTA may contribute to the long-lasting neuroadaptations after intermittent social defeat stress. CRF receptor antagonism is effective in protecting against the immediate effects of social stress, which becomes evident several weeks later when sensitization and escalation are prevented. In particular, blockade of $\mathrm{CRFR}_{1}$ in the VTA dose-dependently prevented stress-induced cross-sensitization as well as escalated cocaine taking during a $24 \mathrm{~h}$ "binge." The $\mathrm{CRFR}_{2}$ antagonist did not block cross-sensitization but did prevent escalated cocaine taking during a $24 \mathrm{~h}$ "binge," suggesting a possible dissociation between locomotor sensitization and escalated cocaine consumption. Concurrent with the stress-induced changes in behavior, both $\mathrm{CRFR}_{1}$ and $\mathrm{CRFR}_{2}$ antagonism in the VTA attenuated stress-augmented DA release in the NAcSh after an acute cocaine challenge.

Stressful encounters in rodents can cause an increase in maladaptive behaviors and neurochemical responses, which can be prevented by either $\mathrm{CRFR}_{1}$ or $\mathrm{CRFR}_{2}$ antagonism (Heinrichs et al., 1992; Jasnow et al., 1999, 2004; Cooper and Huhman, 2007; Wood et al., 2010). Our results confirm previous findings that prior exposures to certain types of stressors induce dopaminergic cross-sensitization to cocaine in the form of augmented DA release in the NAcSh (Pacchioni et al., 2002, 2007; Miczek et al., 2011; Holly et al., 2012). We also demonstrate here that activation of both $\mathrm{CRFR}_{1}$ and $\mathrm{CRFR}_{2}$ during the social defeat experience is necessary for these stress-induced dopaminergic neuroadaptations and cross-sensitization. Although we also show a blunting effect of CP376395 pretreatment on the DAergic response to cocaine in nonstressed control animals, $\mathrm{CRFR}_{1}$ antagonism has been shown previously to decrease the dopaminergic response to cocaine in the nucleus accumbens when given chronically intracerebroventricularly for 2 weeks before cocaine (Lodge and Grace, 2005).

Dopaminergic cross-sensitization is possibly the result of neuroadaptations stemming from the repeated activation of VTA DA cells during each defeat. Social defeat, restraint, and footshock stress all result in persistent increases in burst firing in VTA DA neurons (Anstrom and Woodward, 2005; Anstrom et al., 2009; Brischoux et al., 2009). Dopaminergic VTA neurons express mRNA for both CRF receptor subtypes (Van Pett et al., 2000; Ungless et al., 2003), so CRF may be playing a role in VTA DA cell activation. CRF neurons projecting from the limbic forebrain and paraventricular nucleus of the hypothalamus corelease glutamate into asymmetric synapses on dopaminergic VTA cells (Tagliaferro and Morales, 2008). As such, repeated activation of DA neurons via CRFR in the VTA may drive the observed dopaminergic cross-sensitization to cocaine.

Although both $\mathrm{CRFR}_{1}$ and $\mathrm{CRFR}_{2}$ are crucial for the development of dopaminergic cross-sensitization, this is not the case for locomotor cross-sensitization. The present results show that the $\mathrm{CRFR}_{1}$ antagonist dose-dependently prevented stress-induced cross-sensitization, whereas the CRFR 2 antagonist was not effective at either dose. In agreement with previous findings, it seems clear that $\mathrm{CRFR}_{1}$ in the VTA is involved in the development of locomotor cross-sensitization due to repeated episodes of stress (Boyson et al., 2011). However, the role of CRFR $_{2}$ in the VTA is less obvious. We speculate that CRF receptors may traffic and relocate within VTA neurons after stressful experiences, which may explain the ineffective pretreatment of a $\mathrm{CRFR}_{2}$ antagonist on locomotor sensitization. After exposure to social defeat stress, $\mathrm{CRFR}_{1}$ within the locus ceruleus is internalized, whereas $\mathrm{CRFR}_{2}$ was externalized to the cell membrane (Wood et al., 2010). This same effect may be occurring within the VTA, such that during the first defeat the $\mathrm{CRFR}_{2}$ may not be sufficiently accessible for pharmacological manipulation, leading to locomotor sensitization after a single stress exposure (Nikulina et al., 1998; Miczek et al., 1999).

The current findings also suggest a dissociation in the role of $\mathrm{CRFR}_{2}$ in the VTA between psychomotor sensitization and escalated cocaine consumption, which is concordant with other findings suggesting a dissociation between sensitization and compulsive cocaine taking during reinstatement and binge consumption (Cador et al., 1995; Deroche et al., 1995). To further support the dissociation between these behaviors, there was no correlation between locomotor sensitization and cocaine taking during a $24 \mathrm{~h}$ "binge" in the present study. This finding agrees with others that have reported a clear distinction between druginduced sensitization and drug taking across different classes of drugs, including heroin and ethanol (Lenoir and Ahmed, 2007; Ribeiro et al., 2008). This dissociation may be a result of the strikingly different nature of these two behaviors. Sensitization is expressed as an increased response to a drug, usually assessed after a passive, acute drug injection (intraperitoneal), whereas self-administration is a far more complex behavior involving active seeking and taking of a drug.

Different aspects of cocaine self-administration were examined many weeks after social stress, including stable FR performance rate (resp/min), PR ("breakpoint"), and a $24 \mathrm{~h}$ unlimited access "binge." Although pretreatment of $\mathrm{CRFR}_{1}$ antagonist increased FR 5 performance rate during the last $3 \mathrm{~d}$ of limited access, this marginal effect was primarily driven by a low response rate by the aCSF nonstressed group. Furthermore, the PR data showed no differences among the groups, suggesting both CRF receptor antagonists were ineffective in altering motivational aspects of cocaine consumption. The most intriguing finding showed both $\mathrm{CRFR}_{1}$ and $\mathrm{CRFR}_{2}$ antagonism in the VTA dosedependently prevented escalated cocaine consumption during a $24 \mathrm{~h}$ "binge," which is in agreement with our previous study regarding the $\mathrm{CRFR}_{1}$ subtype (Boyson et al., 2011). These results add to the growing literature that $\mathrm{CRFR}_{1}$ is involved in reducing 
escalated cocaine consumption (Specio et al., 2008) and both $\mathrm{CRFR}_{1}$ and $\mathrm{CRFR}_{2}$ subtypes are involved in preventing stressinduced reinstatement (Sarnyai et al., 2001; Wang et al., 2005; Blacktop et al., 2011). However, one key distinction of the present study is the use of CRF antagonists to prevent long-term as opposed to transient effects. Here, CRF antagonists are administered $\sim 40 \mathrm{~d}$ before the "binge" but are still able to block escalated cocaine self-administration. These findings suggest that social stress can cause long-term neuroadaptations involving both CRF receptors in the VTA, which may be important in the transition from controlled to compulsive drug use during "binge" conditions.

The current results show a specific role of CRF receptors and DA neurons in the VTA projecting to the NAcSh during stress. Although the present results are limited by a lack of thorough investigation of other ineffective brain sites, the few missed placements, although not definitive, point to specificity for CRF receptors within the VTA. However, the mechanism via which dopaminergic sensitization occurs from VTA-CRF-DA interactions during stress has yet to be elucidated. To date, there have been two hypotheses exploring short- and long-term plasticity of CRF-responsive DA neurons. First, the interaction may be associated with fast events during which a stressful stimulus can enhance the firing rate of action potentials primarily involving NMDAR-mediated transmission (Floresco et al., 2001). These enhancements in synaptic transmission may be primarily associated with $\mathrm{CRFR}_{1}$ on DA neurons, and this may directly increase synaptic plasticity by upregulating NMDAR and CRFR ${ }_{1}$. Second, it may be associated with slow forms of synaptic facilitation, where CRF requires CRF binding protein to increase DA transmission and synaptic plasticity. These slower forms of synaptic activation involve $\mathrm{CRFR}_{2}$ (Ungless et al., 2003) and require an additional step before achieving actions on DA neurons. Although there may be two different mechanisms of action regarding VTA-CRF-DA interactions, it is important to note that both receptors can facilitate DA transmission through a common intracellular phospholipase C-protein kinase C pathway (Ungless et al., 2003; Wanat et al., 2008), which may be involved in stressinduced vulnerability to various aspects of addiction.

In addition to the role of CRF-DA interactions in the VTA during social stress, there may be other factors contributing to the later expression of sensitization and escalated cocaine consumption (Covington et al., 2008). For example, CRF may be involved in the upregulation of brain-derived neurotrophic factor within the VTA. Although the direct manipulation of CRF and brainderived neurotrophic factor receptors in combination has not been tested, there is indirect evidence suggesting both receptors are involved (Miczek et al., 2011; Wang et al., 2013; Walsh et al., 2014). It is also possible that CRF and its receptors may be interacting with norepinephrine and serotonin throughout different brain regions, such as the locus ceruleus, amygdala, BNST, and dorsal raphe (Valentino et al., 1993; Van Bockstaele et al., 1998; Dunn and Swiergiel, 2008). Recently, it was demonstrated that stimulation of the BNST potentiated intra-VTA CRF-induced increases in nucleus accumbens dopamine release (Wanat et al., 2013), suggesting a more complex neurocircuitry. It will be important to expand the anatomical analysis beyond the VTA to other brain sites containing the CRF receptor subtype to examine its relationship to stress-induced locomotor and dopaminergic sensitization as well as escalated cocaine self-administration. In conclusion, the results demonstrate $\mathrm{CRFR}_{1}$ and $\mathrm{CRFR}_{2}$ in the VTA are important in the development of stress-induced sensitization and escalated cocaine consumption.

\section{References}

Anstrom KK, Woodward DJ (2005) Restraint increases dopaminergic burst firing in awake rats. Neuropsychopharmacology 30:1832-1840. CrossRef Medline

Anstrom KK, Miczek KA, Budygin EA (2009) Increased phasic dopamine signaling in the mesolimbic pathway during social defeat in rats. Neuroscience 161:3-12. CrossRef Medline

Bale TL, Vale WW (2004) CRF and CRF receptors: role in stress responsivity and other behaviors. Annu Rev Pharmacol Toxicol 44:525-557. CrossRef Medline

Blacktop JM, Seubert C, Baker DA, Ferda N, Lee G, Graf EN, Mantsch JR (2011) Augmented cocaine seeking in response to stress or CRF delivered into the ventral tegmental area following long-access self-administration is mediated by CRF receptor type 1 but not CRF receptor type 2. J Neurosci 31:11396-11403. CrossRef Medline

Borgland SL, Malenka RC, Bonci A (2004) Acute and chronic cocaineinduced potentiation of synaptic strength in the ventral tegmental area: electrophysiological and behavioral correlates in individual rats. J Neurosci 24:7482-7490. CrossRef Medline

Boyson CO, Miguel TT, Quadros IM, DeBold JF, Miczek KA (2011) Prevention of social stress-escalated cocaine self-administration by CRF-R1 antagonist in the rat VTA. Psychopharmacology (Berl) 218:257-269. CrossRef Medline

Brady KT, Sinha R (2005) Co-occurring mental and substance use disorders: the neurobiological effects of chronic stress. Am J Psychiatry 162: 1483-1493. CrossRef Medline

Brischoux F, Chakraborty S, Brierley DI, Ungless MA (2009) Phasic excitation of dopamine neurons in ventral VTA by noxious stimuli. Proc Natl Acad Sci U S A 106:4894-4899. CrossRef Medline

Cador M, Bjijou Y, Stinus L (1995) Evidence of a complete independence of the neurobiological substrates for the induction and expression of behavioral sensitization to amphetamine. Neuroscience 65:385-395. CrossRef Medline

Cooper MA, Huhman KL (2007) Corticotropin-releasing factor receptors in the dorsal raphe nucleus modulate social behavior in Syrian hamsters. Psychopharmacology (Berl) 194:297-307. CrossRef Medline

Covington HE III, Miczek KA (2001) Repeated social-defeat stress, cocaine or morphine: effects on behavioral sensitization and intravenous cocaine self-administration “binges.” Psychopharmacology (Berl) 158:388-398. Medline

Covington HE III, Tropea TF, Rajadhyaksha AM, Kosofsky BE, Miczek KA (2008) NMDA receptors in the rat VTA: a critical site for social stress to intensify cocaine taking. Psychopharmacology (Berl) 197:203-216. CrossRef Medline

Deroche V, Marinelli M, Maccari S, Le Moal M, Simon H, Piazza PV (1995) Stress-induced sensitization and glucocorticoids: 1. Sensitization of dopamine-dependent locomotor effects of amphetamine and morphine depends on stress-induced corticosterone secretion. J Neurosci 15:71817188. Medline

Dunn AJ, Swiergiel AH (2008) The role of corticotropin-releasing factor and noradrenaline in stress-related responses, and the inter-relationships between the two systems. Eur J Pharmacol 583:186-193. CrossRef Medline

Fiorillo CD, Williams JT (1998) Glutamate mediates an inhibitory postsynaptic potential in dopamine neurons. Nature 394:78-82. CrossRef Medline

Floresco SB, Todd CL, Grace AA (2001) Glutamatergic afferents from the hippocampus to the nucleus accumbens regulate activity of ventral tegmental area dopamine neurons. J Neurosci 21:4915-4922. Medline

Goeders NE (2002) Stress and cocaine addiction. J Pharmacol Exp Ther 301:785-789. CrossRef Medline

Heinrichs SC, Pich EM, Miczek KA, Britton KT, Koob GF (1992) Corticotropin-releasing factor antagonist reduces emotionality in socially defeated rats via direct neurotropic action. Brain Res 581:190-197. CrossRef Medline

Henry B, Vale W, Markou A (2006) The effect of lateral septum corticotropin-releasing factor receptor 2 activation on anxiety is modulated by stress. J Neurosci 26:9142-9152. CrossRef Medline

Holly EN, Shimamoto A, DeBold JF, Miczek KA (2012) Sex differences in behavioral and neural cross-sensitization and escalated cocaine taking as a result of episodic social defeat stress in rats. Psychopharmacology (Berl) 224:179-188. CrossRef Medline 
Jasnow AM, Banks MC, Owens EC, Huhman KL (1999) Differential effects of two corticotropin-releasing factor antagonists on conditioned defeat in male Syrian hamsters (Mesocricetus auratus). Brain Res 846:122-128. CrossRef Medline

Jasnow AM, Davis M, Huhman KL (2004) Involvement of central amygdalar and bed nucleus of the stria terminalis corticotropin-releasing factor in behavioral responses to social defeat. Behav Neurosci 118:1052-1061. CrossRef Medline

Koob GF (1999) Stress, corticotropin-releasing factor, and drug addiction. Ann N Y Acad Sci 897:27-45. CrossRef Medline

Koob GF, Zorrilla EP (2010) Neurobiological mechanisms of addiction: focus on corticotropin-releasing factor. Curr Opin Investig Drugs 11:63-71. Medline

Lenoir M, Ahmed SH (2007) Heroin-induced reinstatement is specific to compulsive heroin use and dissociable from heroin reward and sensitization. Neuropsychopharmacology 32:616-624. CrossRef Medline

Lodge DJ, Grace AA (2005) Acute and chronic corticotropin-releasing factor 1 receptor blockade inhibits cocaine-induced dopamine release: correlation with dopamine neuron activity. J Pharmacol Exp Ther 314: 201-206. CrossRef Medline

Miczek KA, Nikulina E, Kream RM, Carter G, Espejo EF (1999) Behavioral sensitization to cocaine after a brief social defeat stress: $c$ - fos expression in the PAG. Psychopharmacology 141:225-234. CrossRef Medline

Miczek KA, Yap JJ, Covington HE 3rd (2008) Social stress, therapeutics and drug abuse: preclinical models of escalated and depressed intake. Pharmacol Ther 120:102-128. CrossRef Medline

Miczek KA, Nikulina EM, Shimamoto A, Covington HE 3rd (2011) Escalated or suppressed cocaine reward, tegmental BDNF and accumbal dopamine due to episodic vs continuous social stress in rats. J Neurosci 31:9848-9857. CrossRef Medline

Nikulina EM, Marchand JE, Kream RM, Miczek KA (1998) Behavioral sensitization to cocaine after a brief social stress is accompanied by changes in fos expression in the murine brainstem. Brain Res 810:200-210. CrossRef Medline

Nikulina EM, Covington HE 3rd, Ganschow L, Hammer RP Jr, Miczek KA (2004) Long-term behavioral and neuronal cross-sensitization to amphetamine induced by repeated brief social defeat stress: Fos in the ventral tegmental area and amygdala. Neuroscience 123:857-865. CrossRef Medline

Pacchioni AM, Gioino G, Assis A, Cancela LM (2002) A single exposure to restraint stress induces behavioral and neurochemical sensitization to stimulating effects of amphetamine: involvement of NMDA receptors. Ann N Y Acad Sci 965:233-246. CrossRef Medline

Pacchioni AM, Cador M, Bregonzio C, Cancela LM (2007) A glutamatedopamine interaction in the persistent enhanced response to amphetamine in nucleus accumbens core but not shell following a single restraint stress. Neuropsychopharmacology 32:682-692. CrossRef Medline

Paxinos G, Watson C (1997) The rat brain in stereotaxic coordinates, Ed 3. San Diego: Academic.

Ribeiro AF, Pigatto G, Goeldner FO, Lopes JF, de Lacerda RB (2008) Lack of relation between drug-seeking behavior in an addiction model and the expression of behavioral sensitization in response to ethanol challenge in mice. J Neural Transm 115:43-54. CrossRef Medline

Richardson NR, Roberts DC (1996) Progressive ratio schedules in drug selfadministration studies in rats: a method to evaluate reinforcing efficacy. J Neurosci Methods 66:1-11. CrossRef Medline

Saal D, Dong Y, Bonci A, Malenka RC (2003) Drugs of abuse and stress trigger a common synaptic adaptation in dopamine neurons. Neuron 37:577-582. CrossRef Medline

Sarnyai Z, Shaham Y, Heinrichs SC (2001) The role of corticotropinreleasing factor in drug addiction. Pharmacol Rev 53:209-243. Medline

Sawchenko PE, Imaki T, Potter E, Kovács K, Imaki J, Vale W (1993) The functional neuroanatomy of corticotropin-releasing factor. Ciba Found Symp 172:5-21; discussion 21-29. Medline

Shaham Y, Erb S, Stewart J (2000) Stress-induced relapse to heroin and cocaine seeking in rats: a review. Brain Res Rev 33:13-33. CrossRef Medline

Shimamoto A, DeBold JF, Holly EN, Miczek KA (2011) Blunted accumbal dopamine response to cocaine following chronic social stress in female rats: exploring a link between depression and drug abuse. Psychopharmacology (Berl) 218:271-279. CrossRef Medline

Sinha R (2009) Stress and addiction: a dynamic interplay of genes, environment, and drug intake. Biol Psychiatry 66:100-101. CrossRef Medline

Specio SE, Wee S, O’Dell LE, Boutrel B, Zorrilla EP, Koob GF (2008) CRF(1) receptor antagonists attenuate escalated cocaine self-administration in rats. Psychopharmacology (Berl) 196:473-482. CrossRef Medline

Swanson LW, Sawchenko PE, Rivier J, Vale WW (1983) Organization of ovine corticotropin-releasing factor immunoreactive cells and fibers in the rat brain: an immunohistochemical study. Neuroendocrinology 36 : 165-186. CrossRef Medline

Tagliaferro P, Morales M (2008) Synapses between corticotropin-releasing factor-containing axon terminals and dopaminergic neurons in the ventral tegmental area are predominantly glutamatergic. J Comp Neurol 506: 616-626. CrossRef Medline

Ungless MA, Singh V, Crowder TL, Yaka R, Ron D, Bonci A (2003) Corticotropin-releasing factor requires CRF binding protein to potentiate NMDA receptors via CRF receptor 2 in dopamine neurons. Neuron 39: 401-407. CrossRef Medline

Vale W, Spiess J, Rivier C, Rivier J (1981) Characterization of a 41-residue ovine hypothalamic peptide that stimulates secretion of corticotropin and beta-endorphin. Science 213:1394-1397. CrossRef Medline

Valentino RJ, Foote SL, Page ME (1993) The locus coeruleus as a site for integrating corticotropin-releasing factor and noradrenergic mediation of stress responses. Ann N Y Acad Sci 697:173-188. CrossRef Medline

Van Bockstaele EJ, Colago EE, Valentino RJ (1998) Amygdaloid corticotropin-releasing factor targets locus coeruleus dendrites: substrate for the co-ordination of emotional and cognitive limbs of the stress response. J Neuroendocrinol 10:743-757. CrossRef Medline

Van Pett K, Viau V, Bittencourt JC, Chan RK, Li HY, Arias C, Prins GS, Perrin M, Vale W, Sawchenko PE (2000) Distribution of mRNAs encoding CRF receptors in brain and pituitary of rat and mouse. J Comp Neurol 428:191-212. CrossRef Medline

Walsh JJ, Friedman AK, Sun H, Heller EA, Ku SM, Juarez B, Burnham VL, Mazei-Robison MS, Ferguson D, Golden SA, Koo JW, Chaudhury D, Christoffel DJ, Pomeranz L, Friedman JM, Russo SJ, Nestler EJ, Han MH (2014) Stress and CRF gate neural activation of BDNF in the mesolimbic reward pathway. Nat Neurosci 17:27-29. CrossRef Medline

Wanat MJ, Hopf FW, Stuber GD, Phillips PE, Bonci A (2008) Corticotropin-releasing factor increases mouse ventral tegmental area dopamine neuron firing through a protein kinase $\mathrm{C}$-dependent enhancement of Ih. J Physiol 586:2157-2170. CrossRef Medline

Wanat MJ, Bonci A, Phillips PE (2013) CRF acts in the midbrain to attenuate accumbens dopamine release to rewards but not their predictors. Nat Neurosci 16:383-385. CrossRef Medline

Wang B, Shaham Y, Zitzman D, Azari S, Wise RA, You ZB (2005) Cocaine experience establishes control of midbrain glutamate and dopamine by corticotropin-releasing factor: a role in stress-induced relapse to drug seeking. J Neurosci 25:5389-5396. CrossRef Medline

Wang J, Fanous S, Terwilliger EF, Bass CE, Hammer RP Jr, Nikulina EM (2013) BDNF overexpression in the ventral tegmental area prolongs social defeat stress-induced cross-sensitization to amphetamine and increases DeltaFosB expression in mesocorticolimbic regions of rats. Neuropsychopharmacology 38:2286-2296. CrossRef Medline

Weiss F, Ciccocioppo R, Parsons LH, Katner S, Liu X, Zorrilla EP, Valdez GR, Ben Shahar O, Angeletti S, Richter RR (2001) Compulsive drug-seeking behavior and relapse: neuroadaptation, stress, and conditioning factors. Ann N Y Acad Sci 937:1-26. CrossRef Medline

Wood SK, Walker HE, Valentino RJ, Bhatnagar S (2010) Individual differences in reactivity to social stress predict susceptibility and resilience to a depressive phenotype: role of corticotropin-releasing factor. Endocrinology 151:1795-1805. CrossRef Medline 